\title{
Sand addition alters the invertebrate community of intertidal coralline turf
}

\author{
Tonya M. Huff ${ }^{1, *}$, Jessica K. Jarett ${ }^{2}$ \\ ${ }^{1}$ Scripps Institution of Oceanography, La Jolla, California 92093, USA \\ ${ }^{2}$ Southampton College, Long Island University, Southampton, New York 11968, USA
}

\begin{abstract}
Many rocky intertidal areas are subject to periodic sand inundations due to a natural cycle of sand movement that is being altered and intensified by human activities. Though sand is thought to be a major structuring force in intertidal communities, little experimental research has been done to investigate its effects on intertidal organisms. Assemblages of meio- and macrofauna that inhabit intertidal coralline algal turf have been especially neglected in regards to manipulative research on the effects of sand. In this study sand was added daily to coralline turf plots to maintain depths of either 3 or $6 \mathrm{~cm}$ for $1 \mathrm{mo}$. Within $1 \mathrm{~h}$ of sand addition, faunal community composition had changed significantly due to a decrease in the abundances of highly mobile animals. Another shift was seen 2 wk later when abundances of psammophilic gastropods increased. One month after sand addition had ceased, communities in treatment plots again resembled those of the controls. This experiment demonstrated that turf communities rapidly respond to and recover from local physical disturbances due to sand inundation.
\end{abstract}

KEY WORDS: Algal turf - Sand inundation - Meiofauna · Coralline algae $\cdot$ Rocky intertidal Disturbance

Resale or republication not permitted without written consent of the publisher

\section{INTRODUCTION}

In many areas worldwide, significant portions of rocky shorelines are covered by a carpet-like mat of algal thalli referred to as algal turf. In San Diego County, California, turf is composed of a few anchor species that attach directly to the substrate (usually Corallina spp.) and many epiphytes that attach to the anchor species (Stewart 1982). At times, large amounts of sediment can be observed within the algal mat and the presence or absence of this sand is an important factor to be considered when studying the turf community (Stewart 1983). The complex mat of algae and associated sediment provides habitat for diverse assemblages of small invertebrates and larvae (Dommasnes 1969, Neumann et al. 1970, Edgar 1983, Hicks 1985, Gibbons \& Griffiths 1986, Akioka et al. 1999, Kelaher et al. 2001). Abundances in excess of 200000 animals $\mathrm{m}^{-2}$ (>500 $\mu \mathrm{m}$ in size) have been previously observed in these turf communities (Brown \& Taylor
1999) and personal observations have shown densities as high as $1.6 \times 10^{6}$ animals $\mathrm{m}^{-2}$ (>63 $\mu \mathrm{m}$ in size).

These invertebrates form an important component of the food chain in the rocky intertidal zone and, hence, are significant players in the system (Coull \& Wells 1983, Coull 1988). According to Coull (1988), more than 50 papers have been published since the early 1970s that document the presence of meiofaunal prey in the stomach contents of marine fish and invertebrate predators. Gut analysis of the intertidal blenny Helcogramma medium indicated that amphipods were their primary prey (Coull \& Wells 1983) and Hicks (1984) found that benthic copepods were the dominant prey for young flatfish. Additionally, Gosselfin \& Chia (1994) found that juvenile Nucella emarginata commonly preyed upon small bivalves such as Lasaea spp. and juvenile Mytilus spp. Dierschke (1994) also determined that the main prey species of the purple sandpiper Calidris maritima included small snails such as Littorina saxatilis, small crustaceans, polychaetes, 
juvenile Mytilus spp. and the isopod Idotea granulosa. All of these examples include prey species that are often part of the turf community.

Evidence suggests that 6000 yr ago most of the southern California shoreline was rocky habitat. With a rise in sea level sand that previously may have fallen into the deep sea began to accrete on the ocean shelf and bury much of this rocky environment (Graham et al. 2003). This has resulted in a fragmentation of rocky areas and has caused a shift to an intertidal community that appears to be moderately tolerant of episodic sand burial (Littler et al. 1983, 1991). Currently, many rocky shores experience sand levels that are variable in both space and time. Additionally, these sand cycles are being altered and intensified by human activities such as the building of seawalls and beach replenishment (AMEC 2002).

Though the dynamics of sand movement are thought to be a major structuring agent on rocky intertidal shores (e.g. Daly \& Mathieson 1977, Taylor \& Littler 1982, McQuaid \& Dower 1990, Airoldi 2003), there is a need for experimental work to investigate the effects of sand on the organisms that inhabit these shores (but see Kendrick 1991, Airoldi \& Cinelli 1997, and Airoldi \& Virgilio 1998 for subtidal work). Limited observational studies of the effects of sand inundation on assemblages of meio- and macrofauna in coralline algal turf have been published (Kelaher et al. 2001, Prathep et al. 2003). Kelaher et al. (2001) showed that of 4 environmental variables, sediment showed the strongest relationship with macrofaunal assemblages in coralline turf. However, experimental work was still needed to follow up on this observation.

The goal of our study was to use experimental techniques to investigate the role of sediment in intertidal coralline turf habitat, particularly in relation to complete burial by sand. Our primary questions were: (1) How does the coralline turf macro- and meiofauna community change with sand burial? (2) Which organisms appear to be sand-tolerant or sand-intolerant? (3) Does the turf faunal community respond differently to burial by different depths of sand? (4) Does the response of the turf faunal community to sand burial change with time?

\section{MATERIALS AND METHODS}

Study site. This experiment was conducted in the Scripps Coastal Reserve at Dike Rock, La Jolla, California $\left(32^{\circ} 87^{\prime} \mathrm{N}, 117^{\circ} 25^{\prime} \mathrm{W}\right)$. Dike Rock has many boulders as well as a flat shelf of mudstone covered with coralline algal turf and is bordered on either side by sandy beach. Experimental plots were located on the shelf in the mid- to low intertidal zones. Turf in this area consists mainly of Corallina pinnatifolia Daws with occasional C. officinalis Kütz as anchor species and epiphytic Ulva californica Wille, Gelidium spp. Lamouroux, Centroceras clavulatum Montagne, Leathesia difformis Aresch, and Laurencia pacifica Kylin.

Much of the rocky area at this site is subject to periodic burial by sand, ranging from a depth of several centimeters to more than a meter (T. M. Huff unpubl. data). During the duration of this study, however, very little natural sand was present.

Experimental design and sampling procedure. Three sand treatments were applied to a total of 15 experimental plots: 5 shallow sand addition plots, 5 deep sand addition plots and 5 control plots to which no sand was added. To maintain the desired sand depths for the $24 \mathrm{~h}$ between applications, plots were haphazardly sited in naturally occurring semienclosed circles of boulders where they were protected from the full force of waves. Sand treatments were then randomly assigned to plots.

Sand of a size typical to natural inundations (mean particle size $<1 \mathrm{~mm}$ and $>500 \mu \mathrm{m}$ ) was taken from a nearby beach and placed on plots daily to maintain a depth of $3 \mathrm{~cm}$ (shallow sand treatment) or $6 \mathrm{~cm}$ (deep sand treatment). The tips of the algal turf remained exposed at the shallow sand depth, while turf was completely covered by the deep sand treatment. Care was taken to cover each plot with sand well outside of its boundaries to reduce edge effects.

Each $0.50 \times 0.75 \mathrm{~m}$ plot was divided into six $0.25 \times$ $0.25 \mathrm{~m}$ quadrats. Each of these quadrats was sampled at 1 of 6 times after initial sand addition: $1 \mathrm{~h}, 12 \mathrm{~h}, 1 \mathrm{~d}$, $2 \mathrm{~d}, 2 \mathrm{wk}$ or $4 \mathrm{wk}$. Samples were also taken immediately before sand addition began ('pre-impact') and 1 mo after sand addition had ceased ('recovery'). Each quadrat within a plot was randomly assigned a sampling time and no quadrat was sampled more than once until recovery samples were taken. Pre-impact samples were taken from the area immediately outside the plot frame and recovery samples were taken randomly from any quadrat inside each plot. During every sampling period, 3 samples were taken randomly from within each plot. In addition to taking algal samples, each plot was watched for 5 min after the initial sand addition and animals that emerged were recorded and counted.

Samples were obtained by cutting through the turf mat with a $4.4 \mathrm{~cm}$ diameter $\left(13.8 \mathrm{~cm}^{2}\right)$ metal coring device and carefully scraping the turf from the bedrock with a metal spatula. Samples were placed in tightly sealed plastic containers, taken back to the lab and immediately preserved in ethanol. They were later rinsed on a $63 \mu \mathrm{m}$ sieve. Samples were sorted manually with forceps under a $12 \times$ dissecting microscope. All invertebrates were removed, identified to the low- 
est possible taxonomic level and counted. Although sessile animals attached to algal fronds (e.g. bryozoans, serpulorbid snails, sponges) were commonly found in the turf, these animals were not included in the study because the methods used were not appropriate to quantify them accurately (Kelaher 2002). Once defaunated, the algae and sand were separated, dried in a $60^{\circ} \mathrm{C}$ drying oven until a constant weight was obtained (at least $24 \mathrm{~h}$ ), and weighed.

To avoid bias in our results due to the inadvertent addition of organisms to the study plots directly with the addition of sand, samples of the sand were taken back to the lab and inspected. Invertebrates were removed and counted and those found in large abundances were noted.

Data analysis. For all analyses data from the 3 samples taken during each time period from each plot were averaged to give dry weights of sand and algae and average animal abundances. Inspection of the invertebrate community found in the sand itself along with comparison of pre- and post-impact species assemblages in the turf revealed one organism, a platyhelminth, which appeared to be a direct artifact of sand addition. We believe that this was the only abundant organism imported to the plots with the sand. Therefore, it was removed from all further analyses.

Because samples contained varying amounts of sand and algae, analyses were performed to determine if standardization of sample size was necessary (e.g. animals per dry weight algae or sand rather than animals per sample). A multiple regression was first completed with dry weight of sand and algae as predictor variables and total number of invertebrates as the response variable. Regression coefficients showed that the number of animals was significantly correlated with amount of algae $\left(R^{2}=0.287, p<0.001\right)$, but not with sand $\left(\mathrm{R}^{2}=0.017, \mathrm{p}=0.080\right)$.

Then, to determine if the average amount of algae in each sample was significantly different among the 3 treatments, an ANOVA was performed using average dry weight of algae as the dependent variable and sand treatment (shallow, deep or control) as a factor. No significant differences were found among the weights of algae in the 3 treatments $\left(F_{2,117}=7.191, p=\right.$ 0.110 ) and consequently no standardization of sample size was done.

Analysis of similarities (ANOSIM), non-metric multidimensional scaling (nMDS) and second stage nMDS were used to investigate patterns and quantify changes in the turf communities. Additionally, the similarity percentages method (SIMPER) was used to determine which taxa were contributing to any perceived differences between samples. This type of analysis uses a Bray-Curtis dissimilarity matrix and computes the contribution of each species to the total average dissimilarity between all pairs of inter-group samples. These analyses were performed using Plymouth Routines in Marine Ecological Research (PRIMER) software v.5.2.9 (Primer-E 2002).

Abundance $(N)$, taxonomic richness $(S)$ and Pielou's evenness index $\left(J^{\prime}\right)$ were also calculated with PRIMER. These indices were then used as response variables with time as a factor in additional ANOVAs to look for changes in abundance and diversity through time within each sand treatment.

\section{RESULTS}

\section{Overview}

A total of 44090 invertebrates from 133 taxa were counted (Table 1). The taxonomic resolution of the fauna varied among groups because some species have not been described, others require specialized taxonomic knowledge to identify and some were juveniles that could not be conclusively identified. The use of differing (i.e. higher) levels of taxonomic discrimination in these types of multivariate analyses has little effect on the outcome (Herman \& Heip 1988, Warwick 1988a,b, James et al. 1995).

Animals were observed immediately emerging from experimental plots after sand addition. Counts made during the $5 \mathrm{~min}$ after initial sand addition showed that these animals mostly included amphipods, isopods, pycnogonids, hermit crabs and larger gastropods (Table 2).

\section{Time and sand depth}

No significant differences existed among the invertebrate assemblages of control, shallow and deep treatment plots before sand was added (ANOSIM, Table 3). With sand addition significant differences were found between both shallow and deep sand treatments and control plots during every sampling interval with 2 exceptions; no significant difference was found between deep treatment and control plots in the 1 or $2 \mathrm{~d}$ samples (Table 3). The nMDS plots also revealed a distinct separation between the communities of control plots and those of plots to which sand had been added (Fig. 1). There were no significant differences between the communities of shallow and deep sand treatment plots during any sampling period (Table 3). Samples taken 1 mo after the cessation of sand addition to determine the recovery response showed no significant differences among the fauna of shallow, deep and control plots (Table 3). 
Table 1. Taxa found in coralline turf samples

\begin{tabular}{|c|c|c|c|}
\hline Phylum & Class or subclass & No. of taxa & Highest resolution \\
\hline \multirow[t]{2}{*}{ Annelida } & Polychaeta & 10 & Family - 8, Genus - 2 \\
\hline & Oligochaeta & 1 & Family - 1 \\
\hline \multirow[t]{7}{*}{ Arthropoda } & Ostracoda & 8 & Genus -6 , Species -2 \\
\hline & Copepoda & 1 & Order -1 \\
\hline & Cirripedia & 3 & Genus - 2, Species - 1 \\
\hline & Malacostraca & 10 & Order -3 , Suborder -3, Genus -2, Species -2 \\
\hline & Cheliceriformes & 1 & Suborder -1 \\
\hline & Pycnogonida & 1 & Class -1 \\
\hline & Insecta & 1 & Family - 1 \\
\hline Cnidaria & Anthozoa & 1 & Genus - 1 \\
\hline \multirow[t]{2}{*}{ Echinodermata } & Ophiuroidea & 1 & Class -1 \\
\hline & Echinoidea & 1 & Genus - 1 \\
\hline \multirow[t]{3}{*}{ Mollusca } & Polyplacophora & 4 & Species -4 \\
\hline & Gastropoda & 65 & Order - 1, Genus - 9, Species - 55 \\
\hline & Bivalvia & 18 & Family - 2, Genus - 5, Species - 11 \\
\hline Nematoda & - & 1 & Phylum - 1 \\
\hline Platyhelminthes & - & 1 & Phylum - 1 \\
\hline Sarcomastigophora & Granuloreticulosea & 4 & Family -4 \\
\hline Sipuncula & - & 1 & Phylum - 1 \\
\hline
\end{tabular}

Table 2. Visual estimates of numbers of invertebrates that migrated out of treatment plots within 5 min of first sand addition. $\mathrm{S}=$ shallow sand treatment $(3 \mathrm{~cm}), \mathrm{D}=$ deep sand treatment $(6 \mathrm{~cm})$

\begin{tabular}{|c|c|c|c|c|c|c|c|c|c|c|}
\hline $\begin{array}{l}\text { Treat- } \\
\text { ment }\end{array}$ & Alia sp. & Amphipods & $\begin{array}{c}\text { Conus } \\
\text { Califonicus }\end{array}$ & Fish & $\begin{array}{c}\text { Hermit } \\
\text { crabs }\end{array}$ & Isopods & $\begin{array}{c}\text { Pachygrapsus } \\
\text { crassipes }\end{array}$ & Pycnogonids & Other & Total \\
\hline $\mathrm{S}$ & 10 & 30 & 1 & 0 & 1 & 0 & 0 & 0 & 0 & 42 \\
\hline S & 25 & 50 & 0 & 0 & 4 & 0 & 0 & 1 & 1 & 81 \\
\hline S & 1 & 100 & 1 & 1 & 2 & 0 & 0 & 0 & 0 & 105 \\
\hline S & $\begin{array}{l}1 \\
10\end{array}$ & 90 & 1 & 1 & 1 & 5 & 1 & 1 & 1 & 111 \\
\hline $\mathrm{S}$ & 80 & 35 & 0 & 0 & 3 & 1 & 0 & 6 & 0 & 125 \\
\hline $\mathrm{D}$ & 30 & 20 & 0 & 0 & 3 & 1 & 0 & 3 & 0 & 57 \\
\hline $\mathrm{D}$ & 35 & 20 & 1 & 0 & 2 & 2 & 0 & 4 & 4 & 68 \\
\hline $\mathrm{D}$ & 40 & 15 & 0 & 0 & 6 & 3 & 2 & 6 & 1 & 73 \\
\hline $\mathrm{D}$ & 3 & 65 & 0 & 0 & 3 & 0 & 0 & 5 & 3 & 79 \\
\hline $\mathrm{D}$ & 135 & 15 & 0 & 1 & 6 & 3 & 0 & 3 & 0 & 163 \\
\hline
\end{tabular}

Neither the shallow nor deep sand addition treatment showed a different trajectory of community change through time from that seen in the control plots (second stage ANOSIM, df = 14, Global R $=-0.02, \mathrm{p}=$ 0.539). A second stage nMDS plot (Fig. 2) also supports the result that neither sand addition treatment had a different trajectory of community change from the controls. Points from all 3 treatments were relatively evenly dispersed across the plot, and no distinct separations were seen.

\section{Community response}

To determine which taxa were responsible for the dissimilarity between treatments a SIMPER analysis was performed. Highly mobile taxa including copepods, gammarid amphipods and ostracods accounted for the majority of differences between treatment and control plots during the early time periods ( 1 and $12 \mathrm{~h}$, 1 and $2 \mathrm{~d}$ ). Abundances of these taxa show a rapid and sustained decrease with sand addition and an increase to near-control levels in recovery samples (Fig. 3a). A second shift in community composition was seen in the 2 and 4 wk samples when abundances of the gastropods Barleeia spp. and Amphithalamus spp. began to increase. These snails also returned to near-control levels in recovery samples (Fig. 3b).

Total abundance $(N)$ significantly decreased through time in both the shallow and deep sand addition treatments while evenness $\left(J^{\prime}\right)$ significantly increased (ANOVA, Shallow $N$ : $F_{7,32}=3.044, \mathrm{p}=0.014$; Shallow $J^{\prime}: F_{7,32}=2.820, \mathrm{p}=0.021 ;$ Deep $N: F_{7,32}=3.515, \mathrm{p}=$ 0.007; Deep $J^{\prime}: F_{7,32}=4.224, \mathrm{p}=0.002$ ) (Fig. 4). However, no significant differences were seen in abundance or evenness through time in the control plots (ANOVA, 
Table 3. Results of ANOSIM analyses to test for the effect of sand addition. Bonferroni correction for multiple comparisons has been applied $(n=5)$ and $\mathrm{df}=14$ for all tests. $\mathrm{S}=$ shallow sand treatment $(3 \mathrm{~cm}), \mathrm{D}=$ deep sand treatment $(6 \mathrm{~cm})$, $\mathrm{C}=$ control. ${ }^{*}$ Significant value $(\mathrm{p}<0.05)$

\begin{tabular}{|c|c|c|c|}
\hline Time & Treatments & R-statistic & $\mathrm{p}$-value \\
\hline Pre-impact & $\begin{array}{c}\text { Global } \\
\text { S,D } \\
\text { S,C } \\
\text { D,C }\end{array}$ & $\begin{array}{r}0.094 \\
0.056 \\
0.292 \\
-0.068\end{array}$ & $\begin{array}{c}0.132 \\
1 \\
0.160 \\
1\end{array}$ \\
\hline $1 \mathrm{~h}$ & $\begin{array}{c}\text { Global } \\
\text { S,D } \\
\text { S,C } \\
\text { D,C }\end{array}$ & $\begin{array}{r}0.560 \\
-0.040 \\
0.768 \\
0.792\end{array}$ & $\begin{array}{c}0.001^{*} \\
1 \\
0.040^{*} \\
0.040^{*}\end{array}$ \\
\hline $12 \mathrm{~h}$ & $\begin{array}{c}\text { Global } \\
\text { S,D } \\
\text { S,C } \\
\text { D,C }\end{array}$ & $\begin{array}{r}0.608 \\
-0.036 \\
0.896 \\
0.828\end{array}$ & $\begin{array}{c}0.001^{*} \\
1 \\
0.040^{*} \\
0.040^{*}\end{array}$ \\
\hline $1 \mathrm{~d}$ & $\begin{array}{c}\text { Global } \\
\text { S,D } \\
\text { S,C } \\
\text { D,C }\end{array}$ & $\begin{array}{l}0.300 \\
0.076 \\
0.596 \\
0.096\end{array}$ & $\begin{array}{l}0.008^{*} \\
0.950 \\
0.040^{*} \\
\quad 1\end{array}$ \\
\hline $2 \mathrm{~d}$ & $\begin{array}{c}\text { Global } \\
\text { S,D } \\
\text { S,C } \\
\text { D,C }\end{array}$ & $\begin{array}{c}0.338 \\
-0.04 \\
0.772 \\
0.292\end{array}$ & $\begin{array}{c}0.014^{*} \\
1 \\
0.040^{*} \\
0.280\end{array}$ \\
\hline $2 \mathrm{wk}$ & $\begin{array}{c}\text { Global } \\
\text { S,D } \\
\text { S,C } \\
\text { D,C }\end{array}$ & $\begin{array}{l}0.419 \\
0.018 \\
0.925 \\
0.960\end{array}$ & $\begin{array}{c}0.001^{*} \\
1 \\
0.040^{*} \\
0.040^{*}\end{array}$ \\
\hline $4 \mathrm{wk}$ & $\begin{array}{c}\text { Global } \\
\text { S,D } \\
\text { S,C } \\
\text { D,C }\end{array}$ & $\begin{array}{r}0.423 \\
-0.068 \\
0.588 \\
0.760\end{array}$ & $\begin{array}{c}0.001^{*} \\
1 \\
0.040^{*} \\
0.040^{*}\end{array}$ \\
\hline Recovery & $\begin{array}{c}\text { Global } \\
\text { S,D } \\
\text { S,C } \\
\text { D,C }\end{array}$ & $\begin{array}{l}-0.060 \\
-0.012 \\
-0.088 \\
-0.080\end{array}$ & $\begin{array}{c}0.684 \\
1 \\
1 \\
1\end{array}$ \\
\hline
\end{tabular}

$p>0.05$ in both cases). No significant differences were seen through time in taxonomic richness $(S)$ in any of the treatments (ANOVA, p > 0.05 in all cases).

\section{DISCUSSION}

This study has established that the experimental addition of sand to intertidal coralline turf has almost immediate and sustained effects on the associated meio- and macrofauna. Two distinct shifts in community composition were seen with sand inundation: a rapid exodus of mobile sand-intolerant animals and a more gradual increase in psammophilic ('sand-loving') gastropods. As early as $1 \mathrm{~h}$ after sand addition, significant differences were seen between control and treatment plots. Both observation and statistical analyses suggest that these differences were caused by highly

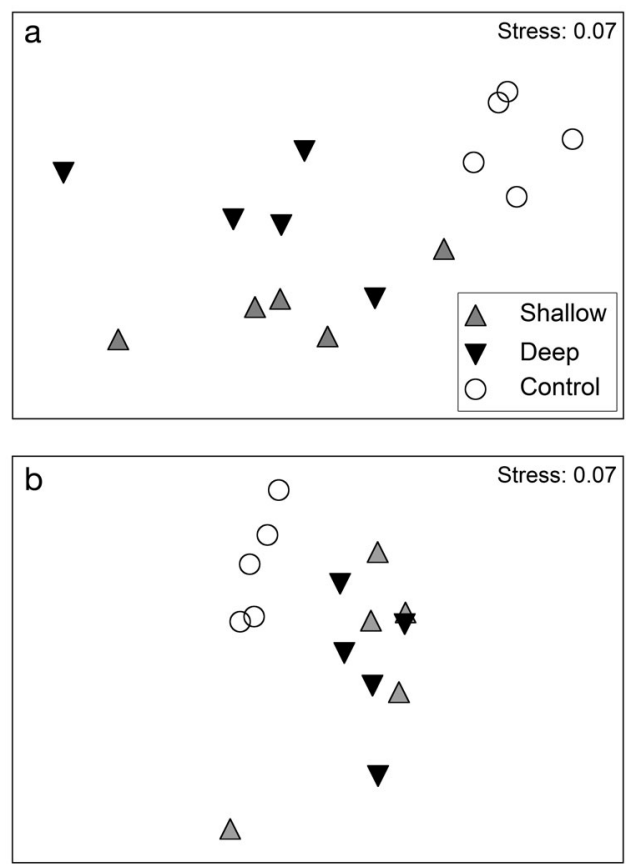

Fig. 1. Representative nMDS plots. (a) nMDS plot showing change in turf community structure $1 \mathrm{~h}$ after sand addition. (b) nMDS plot showing change in turf community structure 4 wk after sand addition

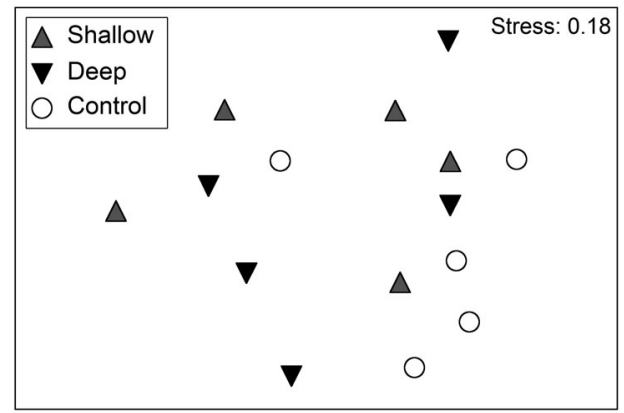

Fig. 2. Second stage nMDS plot indicating no difference in the trajectory of community change among control and sand-added plots

mobile, sand-intolerant animals such as amphipods and ostracods that rapidly dispersed from sand inundated plots. Amphipods and ostracods both tend to live in interstitial spaces of the algal turf (Coull \& Wells 1983, Gibbons 1988). It is possible that the addition of sediment clogged the coralline algae, thus eliminating their spatial niche and refuge from predators (Coull \& Wells 1983, Dean \& Connell 1987). While they have an exoskeleton, these animals are not protected by a hard shell and increased scour associated with sand addition could also be a cause of their decrease in abundance.

A second difference in community composition between treatment and control plots was apparent begin- 

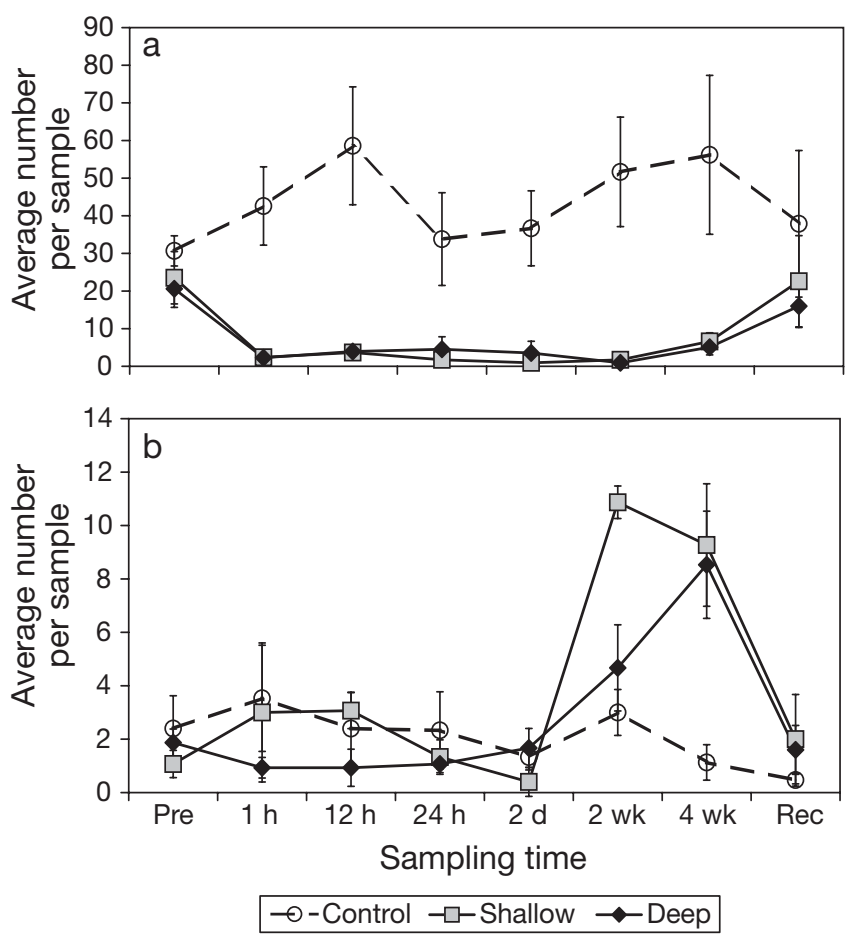

Fig. 3. (a) Average copepod abundance through time for each sand treatment. (b) Average Amphithalamus inclusus abundance through time for each sand treatment. Error bars indicate $\mathrm{SE}$ and $\mathrm{n}=5$

ning in the 2 wk samples when abundances of the snails Amphithalamus tenuis, A. inclusus and Barleeia spp. showed significant increases in treatment plots. Microgastropods are able to move about and disperse into new habitats as adults within a period of days or weeks (Olabarria \& Chapman 2001, Olabarria 2002), so they may respond to habitat changes and move to preferred sites. Amphithalamus spp. are commonly reported to be positively correlated with the presence of sediment (Olabarria \& Chapman 2001, Kelaher et al. 2003) and Barleeia spp. also tend to have higher abundances when more sediment is present (T. M. Huff pers. obs.).

No significant differences were seen between the communities of the shallow and deep sand addition plots. The 2 depths were employed to determine if the community responds differently to different levels of sand burial. While organisms did not distinguish between the 2 sand depths employed in this study, deeper sand depths might produce other changes in the community. Given the immediate response of sand-intolerant organisms to sand addition in this study it is also possible that even minimal levels of sand may affect turf communities.

No significant differences were seen among the trajectories of community change through time for sand-
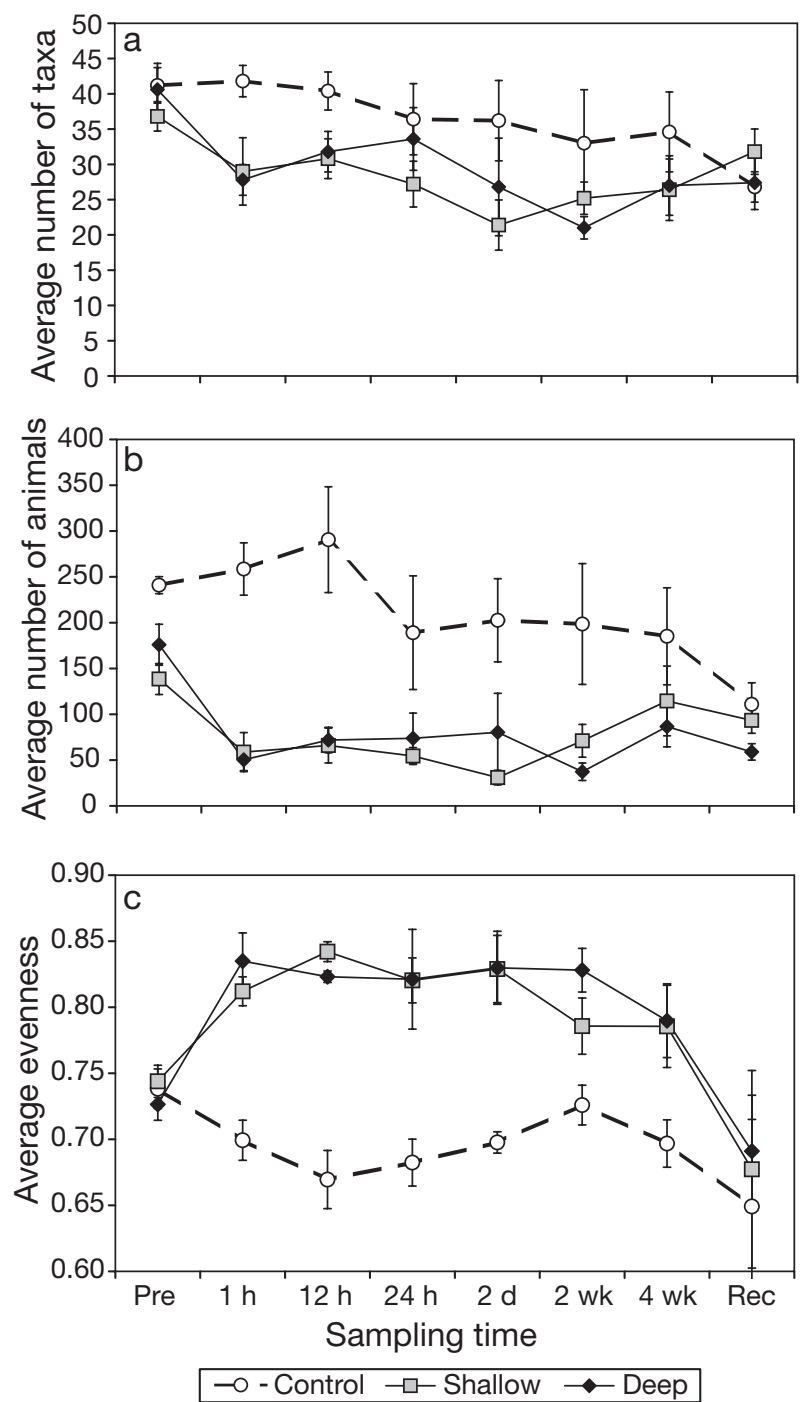

Fig. 4. (a) Average taxonomic richness $(S)$ through time for each sand treatment. (b) Average total abundance $(N)$ through time for each sand treatment. (c) Average Pielou's evenness $\left(J^{\prime}\right)$ through time for each sand treatment. Error bars indicate $\mathrm{SE}$ and $\mathrm{n}=5$

added and control plots. This may be because the majority of community change in treatment plots occurred in 2 pulses. Between these events control and treatment plots would have been subject to similar natural community fluctuations due to variables such as settlement events and disturbances and, therefore, would have had similar trajectories of change.

The anomalous non-significant data points seen in the deep treatment plots for 1 and $2 \mathrm{~d}$ samples deserve some consideration. A random number chart was employed when plots were assigned a particular sand treatment. In hindsight, we noticed that several of the deep treatment plots were located in more energetic areas with more water flow than were the shallow 
plots. In the short term (i.e. 1 and $2 \mathrm{~d}$ samples), this may have changed the impact of the sand addition.

It appears that although sand addition may not significantly alter the number of taxa living in an area, it does alter the relative abundances of these taxa. Since numerically dominant mobile taxa like copepods dramatically decreased in sand plots as compared with control and pre-impact samples (Fig. 3a), we saw a significant decrease in total abundance $(N)$ of organisms in our samples through time in the sand-added plots (Fig. 4). Additionally, since we saw an increase in abundance of scarcer, sand-tolerant taxa in sand plots as the more dominant taxa decreased, an increase in Pielou's evenness index $\left(J^{\prime}\right)$ in these plots makes sense.

The results of this experiment are significant not only because such dramatic changes were seen in the meioand macrofaunal communities, but also because these shifts have the potential to be seen up through the marine food web. As stated previously, meiofauna are important prey for many species of fish and invertebrates. Small macrofauna like those found in turf are also frequently reported as prey items for larger predators (Gibbons \& Griffiths 1986, Dugan et al. 2002). Additionally, meiofauna may play an important role in making detritus available to macroconsumers either through their enhancement of microbial activity or by ingestion of the meiofauna themselves (Coull 1988). We believe that the investigation of the potential effects of changes in the turf community on the larger coastal food web is an important area for future research.

Many questions still remain unanswered about turf communities in relation to periodic sand inundation. This experiment showed a rapid response of turf fauna followed by a relatively rapid recovery as well. However, our experimental plots were small in scale compared with the broad areas of habitat that can be covered with sand during a natural inundation event. Recovery of such a large area might take significantly longer since animals may crawl in from the edges of a small experimental plot more easily than they could if an entire stretch of habitat was inundated. Additionally, this study did not examine how the community is affected by anoxia caused by sand burial or by very long-term inundation events. These are also likely to be fruitful areas for future research.

Acknowledgements. This work was funded by California Sea Grant, the Edna Bailey Sussman Fund and a San Diego Foundation Blasker Environment Grant. The work was done while J.K.J. performed an internship at Scripps made possible by Dr. L. B. Liddle and P. Jackson. We are grateful for permission from reserve manager I. Kay to complete the work in the Scripps Coastal Reserve within the University of California Natural Reserve System. We thank P. Dayton and J. Leichter for valuable guidance, advice and support. P. E. Parnell, L.
Vilchis and C. Catton provided indispensable statistical advice. Many wet, dark early mornings were spent in the intertidal by our field assistants D. Taniguchi, J. Oswald, B. Pister and C. Gonzales. Finally, we acknowledge the important support of A. Knight, I. Castillo, S. Rouse, K. Riser, J. Shaffer, S. Malagong, A. Bachter, J. Cattalano, L. Rouse, H. Huff, N. and D. Tortellini and D. Shaffer.

\section{LITERATURE CITED}

Airoldi L (2003) The effects of sedimentation on rocky coast assemblages. Oceanogr Mar Biol Annu Rev 41:161-236

Airoldi L, Cinelli F (1997) Effects of sedimentation on subtidal macroalgal assemblages: an experimental study from a Mediterranean rocky shore. J Exp Mar Biol Ecol 215: 269-288

Airoldi L, Virgilio M (1998) Responses of turf-forming algae to spatial variations in the deposition of sediments. Mar Ecol Prog Ser 165:271-282

Akioka H, Baba M, Masaki T, Johansen HW (1999) Rocky shore turfs dominated by Corallina (Corallinales, Rhodophyta) in northern Japan. Phycol Res 47:199-206

AMEC Earth and Environment Inc. (2002) Regional beach sand project post-construction monitoring report for intertidal, shallow subtidal, and kelp forest resources. Prepared for San Diego Association of Governments (SANDAG), San Diego, CA

Brown PJ, Taylor RB (1999) Effects of trampling by humans on animals inhabiting coralline algal turf in the rocky intertidal. J Exp Mar Biol Ecol 235:45-53

Coull BC (1988) Ecology of the marine meiofauna. In: Higgins $\mathrm{RP}$, Thiel H (eds) Introduction to the study of meiofauna. Smithsonian Institute Press, Washington, DC, p 18-38

Coull BC, Wells JBJ (1983) Refuges from fish predationexperiments with phytal meiofauna from the New Zealand rocky intertidal. Ecology 64:1599-1609

Daly MA, Mathieson AC (1977) Effects of sand movement on intertidal seaweeds and selected invertebrates at Bound Rock, New Hampshire, USA. Mar Biol 43:45-55

Dean RL, Connell JH (1987) Marine invertebrates in algal succession. III. Mechanisms linking habitat complexity with diversity. J Exp Mar Biol Ecol 109:249-273

Dierschke V (1994) Food and feeding ecology of purple sandpipers Calidris maritima on rocky intertidal habitats (Helgoland, German Bight). Neth J Sea Res 31:309-317

Dommasnes A (1969) On the fauna of Corallina officinalis L. in western Norway. Sarsia 38:71-86

Dugan JE, Hubbard DM, McCrary MD, Pierson MO (2002) The response of macrofauna communities and shorebirds to macrophyte wrack subsidies on exposed sandy beaches of southern California. Estuar Coast Shelf Sci 58S:133-148

Edgar GJ (1983) The ecology of south-east Tasmanian phytal animal communities. I. Spatial organization on a local scale. J Exp Mar Biol Ecol 70:129-157

Gibbons MJ (1988) The impact of sediment accumulations, relative habitat complexity, and elevation on rocky shore meiofauna. J Exp Mar Biol Ecol 122:225-241

Gibbons MJ, Griffiths CL (1986) A comparison of macrofaunal and meiofaunal distribution and standing stock across a rocky shore, with an estimate of their productivities. Mar Biol 93:181-188

Gosselfin LA, Chia FS (1994) Feeding habits of newly hatched juveniles of an intertidal predatory gastropod, Nucella emarginata (Deshayes). J Exp Mar Biol Ecol 176:1-13

Graham MH, Dayton PK, Erlandson JM (2003) Ice ages and 
ecological transitions on temperate coasts. Trends Ecol Evol 18:33-40

Herman PMJ, Heip C (1988) On the use of meiofauna in ecological monitoring: Who needs taxonomy? Mar Pollut Bull 19:665-668

Hicks GRF (1984) Spatio-temporal dynamics of a meiobenthic copepod and the impact of predation disturbance. J Exp Mar Biol Ecol 81:47-72

Hicks GRF (1985) Meiofauna associated with rocky shore algae. In: Moore PG, Seed R (eds) Ecology of rocky coasts. Hodder and Stoughton, London, p 36-56

James RJ, Lincoln Smith MP, Fairweather PG (1995) Sieve mesh-size and taxonomic resolution needed to describe natural spatial variation of marine macrofauna. Mar Ecol Prog Ser 118:187-198

Kelaher BP (2002) Influence of physical characteristics of coralline turf on associated macrofaunal assemblages. Mar Ecol Prog Ser 232:141-148

Kelaher BP, Chapman MG, Underwood AJ (2001) Spatial patterns of diverse macrofaunal assemblages in coralline turf and their associations with environmental variables. J Mar Biol Assoc UK 81:917-930

Kelaher BP, Underwood AJ, Chapman MG (2003) Experimental transplantations of coralline algal turf to demonstrate causes of differences in macrofauna at different tidal heights. J Exp Mar Biol Ecol 282:23-41

Kendrick GA (1991) Recruitment of coralline crusts and filamentous turf algae in the Galapagos Archipelago - effect of simulated scour, erosion, and accretion. J Exp Mar Biol Ecol 147:47-63

Littler MM, Martz DR, Littler DS (1983) Effects of recurrent sand deposition on rocky intertidal organisms: importance of substrate heterogeneity in a fluctuating environment. Mar Ecol Prog Ser 11:129-139

Editorial responsibility: Howard Browman (Associate Editorin-Chief), Storebø, Norway
Littler MM, Littler DS, Murray SN, Seapy RR (1991) Southern California rocky intertidal ecosystems. In: Mathieson AC, Nienhuis PH (eds) Ecosystems of the world. Vol 24. Elsevier, New York, p 273-296

McQuaid CD, Dower KM (1990) Enhancement of habitat heterogeneity and species richness on rocky shores inundated by sand. Oecologia 84:142-144

Neumann AC, Gebelein CD, Scoffin TP (1970) The composition, structure, and erodability of subtidal mats, Abaco, Bahamas. J Sediment Petrol 40:274-297

Olabarria C (2002) Role of colonization in spatio-temporal patchiness of microgastropods in coralline turf habitat. J Exp Mar Biol Ecol 274:121-140

Olabarria C, Chapman MG (2001) Comparisons of patterns of spatial variation of microgastropods between two contrasting intertidal habitats. Mar Ecol Prog Ser 220:201-211

Prathep AR, Marrs H, Norton TA (2003) Spatial and temporal variations in sediment accumulation in an algal turf and their impact on associated fauna. Mar Biol 142:381-390

Stewart JG (1982) Anchor species and epiphytes in intertidal algal turf. Pac Sci 36:45-59

Stewart JG (1983) Fluctuations in the quantity of sediments trapped among algal thalli on intertidal rock platforms in southern California. J Exp Mar Biol Ecol 73:205-211

Taylor PR, Littler MM (1982) The roles of compensatory mortality, physical disturbance, and substrate retention in the development and organization of a sand-influenced, rocky intertidal community. Ecology 63:135-146

Warwick RM (1988a) The level of taxonomic discrimination required to detect pollution effects on marine benthic communities. Mar Pollut Bull 19:259-268

Warwick RM (1988b) Analysis of community attributes of the macrobenthos of Frierfjord/Langesundfjord at taxonomic levels higher than species. Mar Ecol Prog Ser 46:167-170

Submitted: June 8, 2006; Accepted: March 27, 2007

Proofs received from author(s): August 30, 2007 